\title{
Characterization of pervious concrete focusing on non-destructive testing
}

\section{Caracterização do concreto permeável com foco em ensaios não destrutivos}
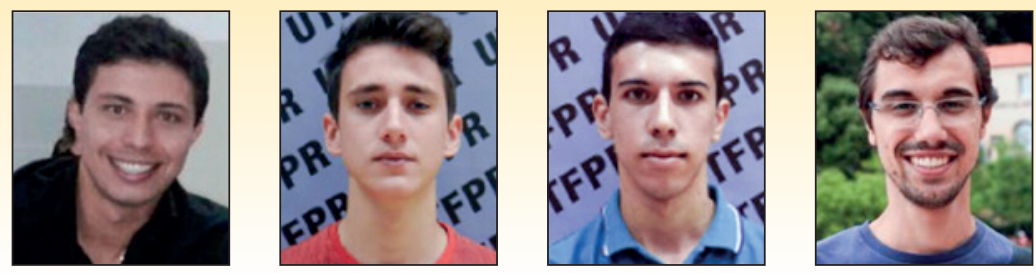

S. T. MARTINS FILHO sergiotunis@hotmail.com https://orcid.org/0000-0002-4334-399X

E. M. BOSQUESI a eduardobosquesi@gmail.com https://orcid.org/0000-0003-3802-0288

J. R. FABRO a

julianofabro@hotmail.com https://orcid.org/0000-0002-1680-9627

R. PIERALISI

ricpieralisi@ufpr.br

https://orcid.org/0000-0001-8339-5324

\begin{abstract}
This study aims to investigate the properties of pervious concrete focusing on characterization tests by the Ultrasound Method. For this, three mixtures were produced with the paste/aggregate $(\mathrm{P} / \mathrm{Ag}$ ) ratio ranging from 0.45 to 0.65 , water to cement ratio (w/c) of 0.3 , and all the specimens were compacted with a steel rod. The application of the ultrasound method deserves special attention for the characterization of pervious concrete, due to a lack of research and the potential to develop analytical models for predicting properties from ultrasonic pulse velocity (UPV) as an independent variable. The UPV obtained in this study ranged from 3642 to $4262 \mathrm{~m} / \mathrm{s}$ for an approximately $12 \%$ reduction in porosity, with a correlation $\left(R^{2}\right)$ of 0.91 . It is noteworthy that the high porosity of pervious concrete causes attenuation of the ultrasonic wave. The measurements of UPV had higher values for specimens with higher densities $\left(R^{2}=0.87\right)$, higher compressive and tensile strengths $\left(R^{2}\right.$ of 0.79 and 0.84 , resp.), and lower permeability $\left(R^{2}=0.91\right)$.
\end{abstract}

Keywords: pervious concrete, ultrasound method, porosity, permeability, compressive strength.

\section{Resumo}

Neste estudo, objetiva-se investigar as propriedades do concreto permeável com foco nos ensaios de caracterização pelo Método do Ultrassom. Para isso, foram produzidos três traços com a relação pasta/agregado variando de 0,45 a 0,65 , relação a/c de 0,3 e compactados por haste. A aplicação do Método do Ultrassom merece atenção especial para caracterização do concreto permeável, com carência de pesquisas e com potencial de desenvolver modelos analíticos de previsão das propriedades a partir da velocidade de pulsos ultrassônicos (VPU) como uma variável independente. A VPU variou de 3642 até $4262 \mathrm{~m} / \mathrm{s}$ para uma redução de aproximadamente $12 \%$ na porosidade, com alta correlação $\left(R^{2}\right)$ de 0,91 e destaca-se que a alta porosidade do concreto provoca atenuação da onda ultrassônica. As medições da VPU retrataram valores maiores para os CPs com maiores densidades $\left(R^{2}=0,87\right)$, maiores resistências à compressão e à tração $\left(R^{2}\right.$ de 0,79 e 0,84 , resp.), e menores permeabilidades $\left(R^{2}=0,91\right)$.

Palavras-chave: concreto permeável, método do ultrassom, porosidade, permeabildiade, resistência à compressão.

Universidade Tecnológica Federal do Paraná, Coordenação de Engenharia Civil, Apucarana, PR, Brasil;

Universidade Federal do Paraná, Centro de Estudos de Engenharia Civil, Programa de Pós-Graduação em Engenharia de Construção Civil, Curitiba, PR, Brasil.

Received: 05 Aug 2019 • Accepted: 10 Dec 2019 • Available Online: 26 May 2020

《ermis is an open-access article distributed under the terms of the Creative Commons Attribution License 


\section{Introduction}

Currently, pervious concrete is used in pavement construction in urban areas, as a way to minimize the impacts caused by conventional impermeable paving. During heavy rainfall, impervious paving contributes to increased runoff of surface waters and potential for sudden flooding [1, 2], and is an effective way to meet growing environmental demands.

Permeability is an intrinsic property of pervious concrete that allows fluid (water) to pass through its matrix [3]. This feature is attributed to the fact that pervious concrete has a network of interconnected macropores that form channels that allow water to drain. Moreover, permeability may be used as a drainage device in retaining walls [4].

Also, pervious concrete is used to reduce the formation of heat islands in cities [5], and helps as a sound barrier, absorbing noise caused by the interaction between tire and pavement [6]. However, pervious concrete is generally used for low traffic demand pavements, since its high porosity decreases its compressive strength $[5,7,8]$

Allied to the environmental aspects, the technical characteristics of pervious concrete arouse an increasing interest for its use in sustainable construction, being promoted by building certification systems (such as the Green Building Council's LEED [1]). Pervious concrete may contribute to some categories in LEED certification, namely: Sustainable Sites; Water efficiency; Materials and Resources; and Design Innovation [9].

In order to optimize the percentage of interconnected pores relative to the total element volume, the traditional mix design philosophies for pervious concrete [10] suggest that the composition is formed by coarse aggregates, a minimal amount of fine aggregates (or, even, no fine aggregates), and cement paste volume sufficient to

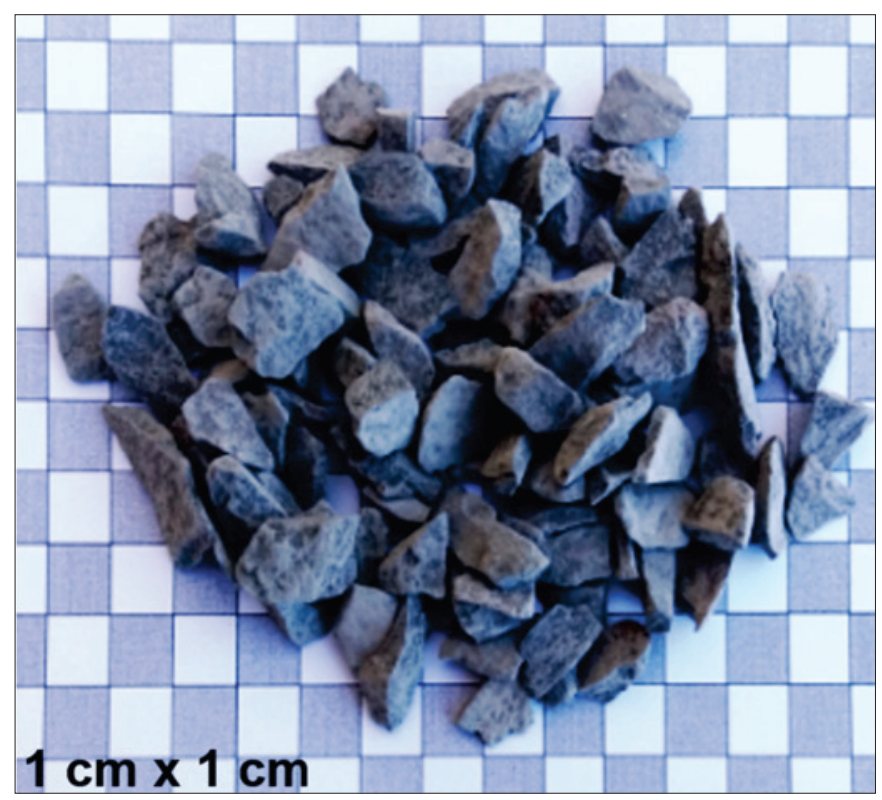

\section{Figure 1}

Surface aspect of the particle size fraction: range 6.3 to $9.5 \mathrm{~mm}$ involve the coarse aggregates. Due to this proportion of materials, pervious concrete has a dry consistency with a slump close to zero [10-12].

The porosity of pervious concrete is a relevant factor in its performance and is related to other properties, such as permeability [12-14]. It is noteworthy that, currently, there is no guideline that regulates the test procedure for the characterization of permeability of pervious concrete in the laboratory. However, for some researchers [12, 15-19], the permeability test may be performed with constant-head permeameter for specimens with high porosity and high permeability. On the other hand, other authors [20-23] perform the test using falling-head permeameter, regardless of the porosity level of the specimens.

In this sense, mix design philosophies of pervious concrete are limited. There is no consolidated and universally accepted theoretical knowledge that relates the mix proportion of the materials and the consolidation process to the hardened properties of the pervious concrete [24]. Moreover, according to ACI 522R-10 [10] pervious concrete mix design has an empirical component based on the experiments already performed. In the usual applications among researchers, it is noted mass mixtures ranging from 1:2 to $1: 12$, with cement consumption ranging from 150 to $700 \mathrm{~kg} / \mathrm{m}^{3}$ and w/c ratio from 0.2 to 0.5 , which conduct to porosities up to $42 \%$ and permeability up to $33 \mathrm{~mm} / \mathrm{s}$ [2].

The first published guidelines for pervious concrete were: PCP manual [1]; and ACI 522R-10 [10]. Both address technical aspects of the material, the constituents, simplified mix design methods, and characterization tests.

In recent years, the American Society for Testing and Materials (ASTM) has released a collection of standards for pervious concrete characterization: ASTM C1754 [25], to determine the density and void content of pervious concrete in the hardened state; ASMT C1747 [26], to determine the degradation resistance of impact and abrasion pervious concrete; ASTM C1688 [27], to determine the density and void content of fresh pervious concrete; ASTM C1701 [28], to determine the permeability of pervious concrete. Recently, the Brazilian Association of Technical Standards (ABNT) also published a standard on pervious concrete, ABNT NBR 16416 [29], which deals with pervious pavement requirements, focusing on interlocking blocks and the in situ permeability characterization test. Although there are standards related to properties characterization of pervious concrete, there are no in-depth standards nor guidelines in the literature on the use of non-destructive tests for indirect characterization of pervious concrete.

The Ultrasound Method is a relevant non-destructive test for the characterization and investigation of conventional concrete [30, 47]. Regarding pervious concrete, there is a little research about this topic, which opens the possibility of developing prediction equations that can help in determining its properties.

The use of an ultrasound test allows the characterization of concrete, detecting flaws, and monitoring its state of deterioration, in addition to estimate its mechanical properties. Generally, the frequency of the transducers used in the tests ranges from 25 to $100 \mathrm{kHz}$ and the ultrasonic pulse velocity (UPV) for conventional concrete is different depending on the mix constitution, its proportion, and the physical characteristics of the aggregates [31]. The 


\section{Table 1}

Dimensions and shape index of the particle size range

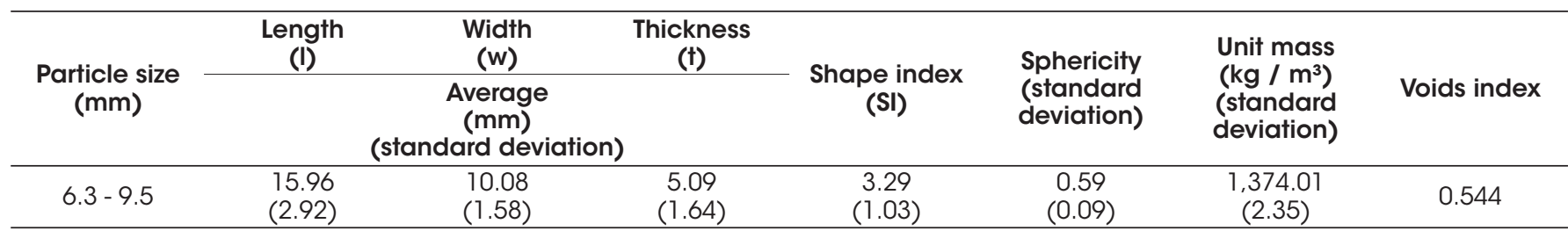

standard for determining ultrasonic pulse velocity (UPV) in concrete follow ASTM C 597 [32]

Because pervious concrete has a high level of porosity, it causes attenuation of the ultrasonic wave. This characteristic leads to an amplification factor between 50 and $60 \mathrm{~dB}$ [33] in order to measure the UPV. In the literature [34, 35] was found that for a higher pervious concrete density, lower porosity and higher compressive strength, the greater the UPV. Also, the authors [34, 35] highlighted the feasibility of using the ultrasound method to perform periodic evaluations on pervious concrete pavements, preserving it from the need for core extraction. From the current state of the art, this paper aims to investigate the properties of pervious concrete focusing on characterization tests by the ultrasound method.

\section{Materials and methods}

\subsection{Materials}

The coarse aggregate was obtained by a sieving process from a granular set of basaltic origin acquired in a quarry located in the region of Apucarana/PR (Brazil). The sieving process followed the recommendations of ABNT NBR NM 248 [36]. The result was the particle size fraction between 6.3 and $9.5 \mathrm{~mm}$. Figure 1 shows the superficial aspect of coarse aggregates.

The obtained particle size fraction was characterized by the following tests: Unit mass, ABNT NBR NM 45 [37]; Shape Index (SI), ABNT NBR 7809 [38]; and Zingg Method [39]. In this sense, three measurements (length, width, and thickness) of 200 aggregates, random selected, were made. Table 1 shows the physical characteristics of the aggregates.

According to the Zinng classification [39], obtained by the values of elongation (ratio between thickness and width) and flatness (ratio between width and length) of the aggregates, the predominant aspect of the aggregates is lamellar elongation. The aggregate classification is important for the understanding of the properties of pervious concrete, which its physical characteristics influence in the compaction process, adversely affecting the contact area between the aggregates and thus leading to different densities and strength $[10,40,44]$.

The material compositions used were defined in order to emulate typical dosages found in pervious concrete applications. According to the literature recommendations [17, 22, 40-42], the aggregates with uniform diameter were selected. The value of Paste/ Aggregate $(\mathrm{P} / \mathrm{Ag})$ ratios was defined in order to obtain pervious concretes with porosity and permeability compatible with the practical application.

Table 2 shows the 3 mix composition defined in this study. The P/Ag volume ranged from 0.45 to 0.65 , assigning the nomenclature to the three mixture of $\mathrm{T} 0.45, \mathrm{~T} 0.55$, and $\mathrm{T} 0.65$. The particle size range used was uniform, with diameters between 6.3 and $9.5 \mathrm{~mm}$, the water/cement ratio $(\mathrm{w} / \mathrm{c})$ was constant for all compositions, and the Portland Cement CP II-Z regulated by ABNT NBR 16697 [43] was used.

The pervious concrete mixing process followed the recommendations of SCHAEFER et al. [44]. After concrete preparation, a visual inspection was performed and it was found that the $w / c$ ratio used to lead to the aggregates entirely covered with paste and in the consolidation process the paste did not segregate, following the recommendations of TENNIS et al. [1]. The consolidation process was performed by throwing the concrete into the cylindrical mold in three layers, each layer was compacted with 25 blows with a steel rod, following the rules of ABNT NBR 45 [37]. In total, 36 cylindrical specimens $(100 \mathrm{~mm}$ in diameter and $200 \mathrm{~mm}$ in height) were produced.

\subsection{Methods}

All the specimens had their density and porosity in the fresh and hardened state, permeability, compressive and tensile strength, and UPV characterized. The density and porosity in the fresh state were obtained using the procedure described by ASTM C1688 [27]. The procedures proposed by ASTM C1754 [25] were used to calculate the density and porosity in the hardened state.

The permeability of pervious concrete was obtained through the constant-head permeameter, which is recommended in the

\section{Table 2}

Mixture proportion of the pervious concrete: the first experimental campaign

\begin{tabular}{ccccccc}
\hline Mixture & $\begin{array}{c}\text { P/Ag ratio by } \\
\text { mass }\end{array}$ & $\begin{array}{c}\text { Aggregate } \\
\text { consumption } \\
\left(\mathbf{k g} / \mathbf{m}^{3}\right)\end{array}$ & $\begin{array}{c}\text { Cement } \\
\text { consumption } \\
\left(\mathbf{k g} / \mathbf{m}^{3}\right)\end{array}$ & Cement & Aggregate & w/c \\
\hline T0.45 & 0.45 & $1,305.91$ & 452.26 & 1 & 2.9 & 0.3 \\
T0.55 & 0.55 & $1,306.85$ & 553.35 & 1 & 2.4 & 0.3 \\
T0.65 & 0.65 & $1,218.81$ & 609.40 & 1 & 2.0 & 0.3 \\
\hline
\end{tabular}




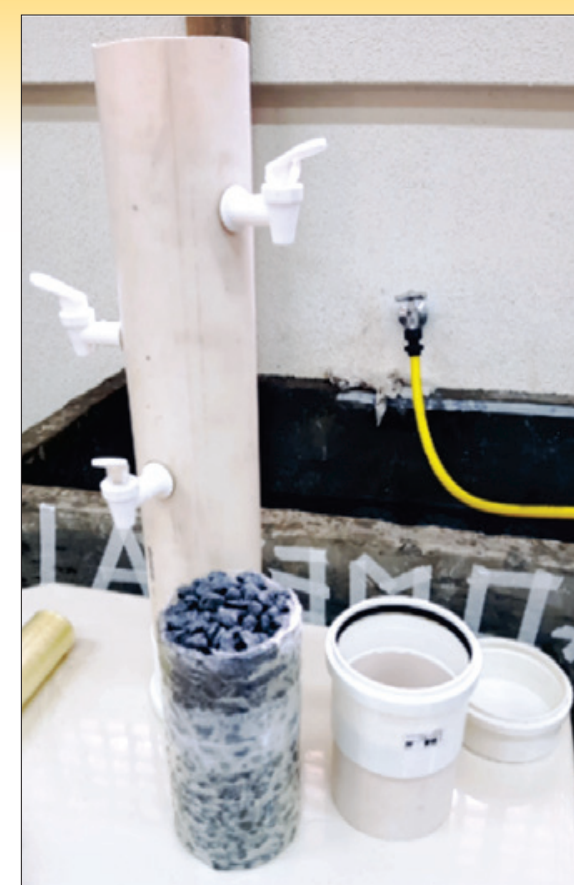

(a)



(b)



(c)

\section{Figure 2}

Process for mounting the permeability test

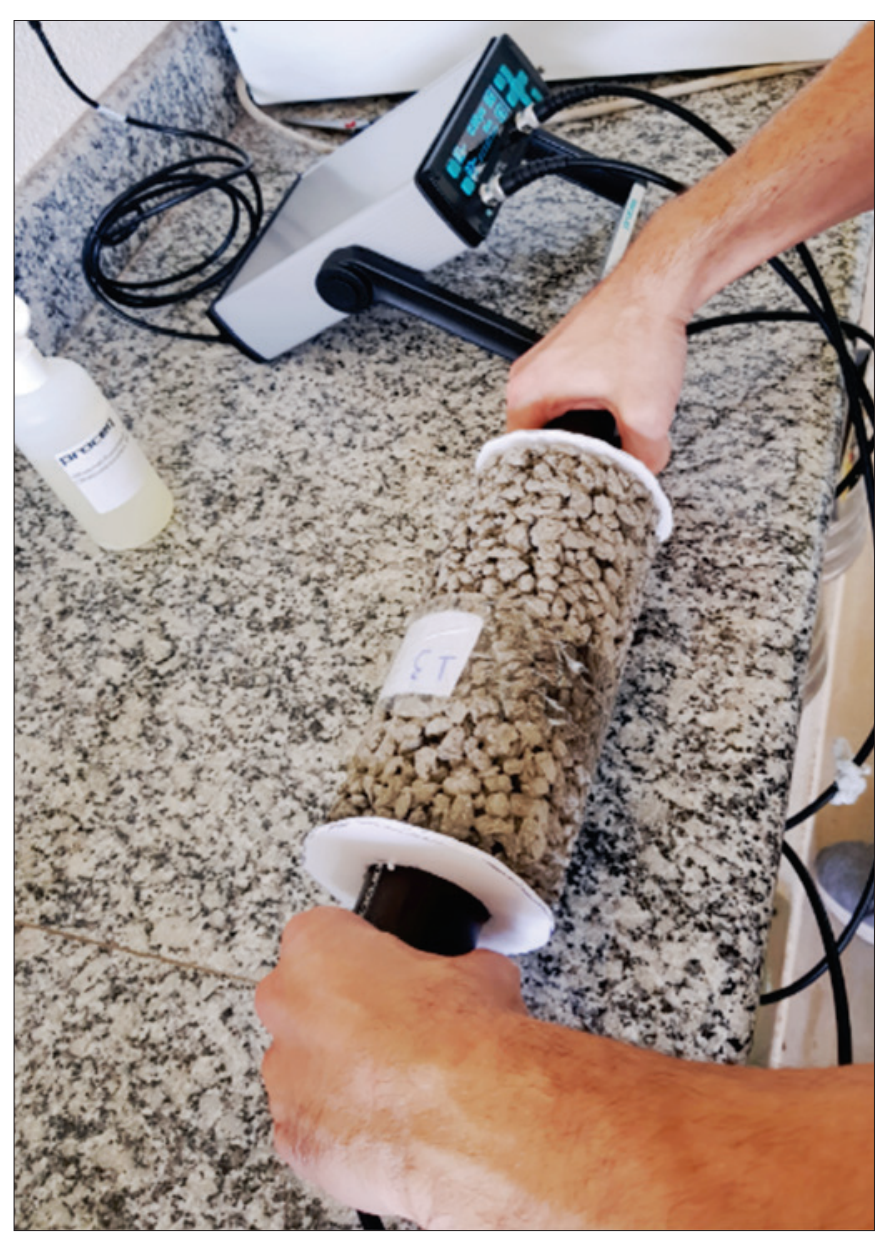

\section{Figure 3}

Ultrasound test: reading by direct longitudinal transmission literature [12,15-19]. Figure 2 shows the constant-head permeameter developed for the test. The permeability results presented in this study were calculated with a hydraulic load of $30 \mathrm{~cm}$.

Once the specimen was coupled with the apparatus, the opening of the bottom tube was closed. Next, the volume of water necessary to fill the bottom tube and the pore spaces of the specimen was measured $\left(q_{1}\right)$. Then, the apparatus was completely filled with water and the bottom tube was opened. Finally, the volume of water that passed through the specimen in $60 \mathrm{~s}$ was measured $\left(\mathrm{q}_{2}\right)$. The permeability $(k)$ was estimated using Darcy's Law according to Equation 1. In this equation $q$ is the difference between both measured volumes of water $\left(q_{2}-q_{1}\right)$, $h$ is the heigth specimen $\left(L_{s}\right)$ plus the hydraulic load $(30 \mathrm{~cm})$, and $t$ is time interval $(60 \mathrm{~s})$.

$k=\frac{4 \cdot q \cdot L_{s}}{\pi \cdot \emptyset_{s}^{2} \cdot h \cdot t}$

The compressive strength was determined according to ABNT NBR 5739 [45]. The bottom and top surfaces of the specimens were regularized with plaster. The tensile strength was determined by diametric compression according to the recommendations of ABNT NBR 7222 [46].

The Ultrasonic Pulse Velocity (UPV) was determined using the PROCEQ/Pundit Lab ultrasound device, following the procedures established in ASTM C597 [32]. The ultrasound measurement was performed in the longitudinal direction (around $20 \mathrm{~cm}$ ) of the specimens, with an ultrasonic wave vibration frequency of $24 \mathrm{kHz}$ and a receiver amplification factor of 500 (which corresponds to $54 \mathrm{~dB}$ ). The test setup consisted of two plates with holes to support the ultrasound transducers for direct measurement, this ensured that the transducers were concentric to the specimen (see Figure 3). According to Chandrappa and Biligiri [34], it is required to apply a thick layer of gel on the top and bottom surfaces of the specimen where the transducers are placed. Finally, the average of three measurements was used as a single UPV value. 
Table 3

Properties of pervious concrete

\begin{tabular}{|c|c|c|c|c|c|c|c|}
\hline Mixture & $\begin{array}{c}\text { Fresh state } \\
\text { density } \\
\left(\mathrm{kg} / \mathrm{m}^{3}\right)\end{array}$ & $\begin{array}{l}\text { Hardened } \\
\text { state density } \\
\left(\mathrm{kg} / \mathrm{m}^{3}\right)\end{array}$ & $\begin{array}{c}\text { Total porosity } \\
\text { (\%) }\end{array}$ & $\begin{array}{c}\text { Compressive } \\
\text { strength (MPa) }\end{array}$ & $\begin{array}{l}\text { Tensile } \\
\text { strength } \\
\text { (MPa) }\end{array}$ & $\begin{array}{c}\text { Permeability } \\
\text { height } \\
30 \mathrm{~cm} \\
(\mathrm{~mm} / \mathrm{s})\end{array}$ & $\begin{array}{l}\text { UPV } \\
(\mathrm{m} / \mathrm{s})\end{array}$ \\
\hline T0.45 & $\begin{array}{l}1,914.85 \\
(23.48)\end{array}$ & $\begin{array}{l}1,893.84 \\
(23.71)\end{array}$ & $\begin{array}{l}28.44 \\
(1.05)\end{array}$ & $\begin{array}{l}7.77 \\
(0.46)\end{array}$ & $\begin{array}{l}1.49 \\
(0.20)\end{array}$ & $\begin{array}{c}8.31 \\
(0.77)\end{array}$ & $\begin{array}{c}3,719.79 \\
(48.91)\end{array}$ \\
\hline T0.55 & $\begin{array}{l}2,046.04 \\
(32.80)\end{array}$ & $\begin{array}{l}2,026.20 \\
(32.41)\end{array}$ & $\begin{array}{l}20.97 \\
(1.62)\end{array}$ & $\begin{array}{l}10.65 \\
(1.07)\end{array}$ & $\begin{array}{l}2.36 \\
(0.34)\end{array}$ & $\begin{array}{l}2.37 \\
(0.99)\end{array}$ & $\begin{array}{c}4,063.50 \\
(73.28)\end{array}$ \\
\hline T0.65 & $\begin{array}{c}2,035.27 \\
(42.38)\end{array}$ & $\begin{array}{c}2,004.08 \\
(42.21)\end{array}$ & $\begin{array}{l}20.93 \\
(2.14) \\
\end{array}$ & $\begin{array}{l}11.73 \\
(1.72)\end{array}$ & $\begin{array}{c}2.33 \\
(0.41) \\
\end{array}$ & $\begin{array}{c}3.15 \\
(0.82) \\
\end{array}$ & $\begin{array}{c}4,163.00 \\
(97.70) \\
\end{array}$ \\
\hline
\end{tabular}

\section{Results e discussions}

Table 3 shows the average and standard deviations (in parenthesis below average) of density (fresh and hardened states), porosity, compressive strength, tensile strength, permeability, and UPV value. From the data obtained in the characterization by the ultrasound method, some correlations can be made in order to understand the behavior of pervious concrete using a nondestructive method.

Figure 4 a shows the relation between UPV and total porosity, notice that the UPV increases as porosity decreases. This behavior is expected because the voids cause attenuation of the ultrasonic wave velocity. Besides, mixtures with a higher P/Ag ratio lead to a low level of porosities, which increase the possibility of the wave to find shorter paths for its propagation and increase the UPV value. Equation 2 presents the relation to obtain total porosity $(P)$ through the independent variables UPV and P/Ag ratio.

$P=105.7576+11.8586 \cdot P / A g-0.022308 \cdot U P V$
Figure $4 \mathrm{~b}$ presents a comparison between the average experimental and estimated porosity for all specimens, including an equivalence line. Results reveal a relative prediction error of the estimation is $0,24 \%$, and a coefficient of correlation (R2) of 0.91 .

Figure 5 a shows the relation between UPV and density at the hardened state. The observed behavior is the opposite of the relation between UPV and Porosity, which means that samples with higher densities (or lower porosities) conduct to higher values of UPV. Equation 3 presents the relation to obtaining density at the hardened state (DE) through the independent variables UPV and P/Ag.

$D E=413,28-457,86 \cdot P / A g+0.45534 \cdot U P V$

Figure $5 \mathrm{~b}$ presents a comparison between the average experimental and estimated densities for all specimens, including an equivalence line. Results reveal a relative prediction error of the estimation is $0,01 \%$, and a coefficient of correlation (R2) of 0.87 .

Figure $6 \mathrm{a}$ presents the comparison between the permeability $(\mathrm{k})$ depending on UPV value. It is observed that specimens with higher

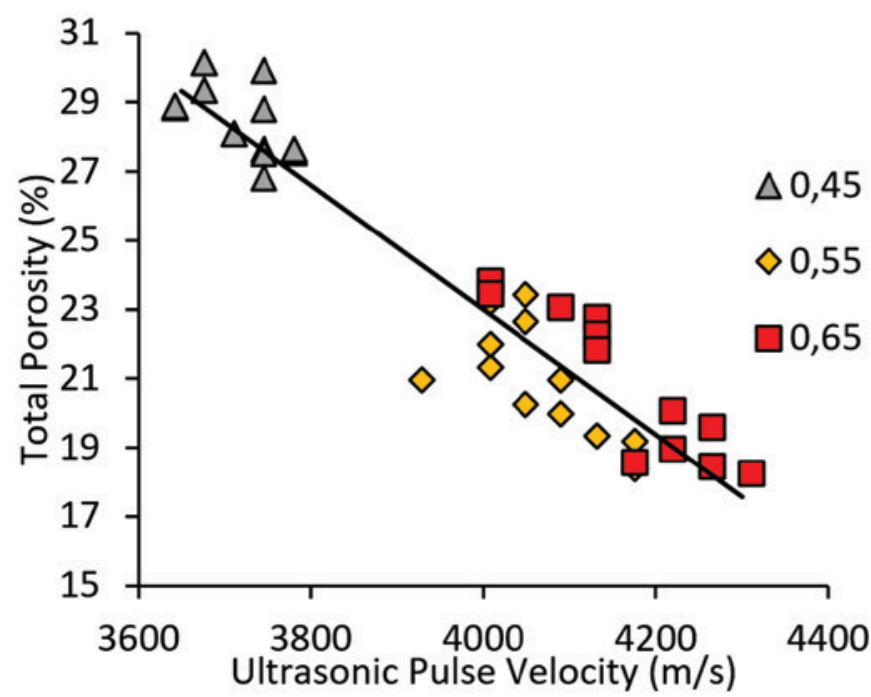

(a)

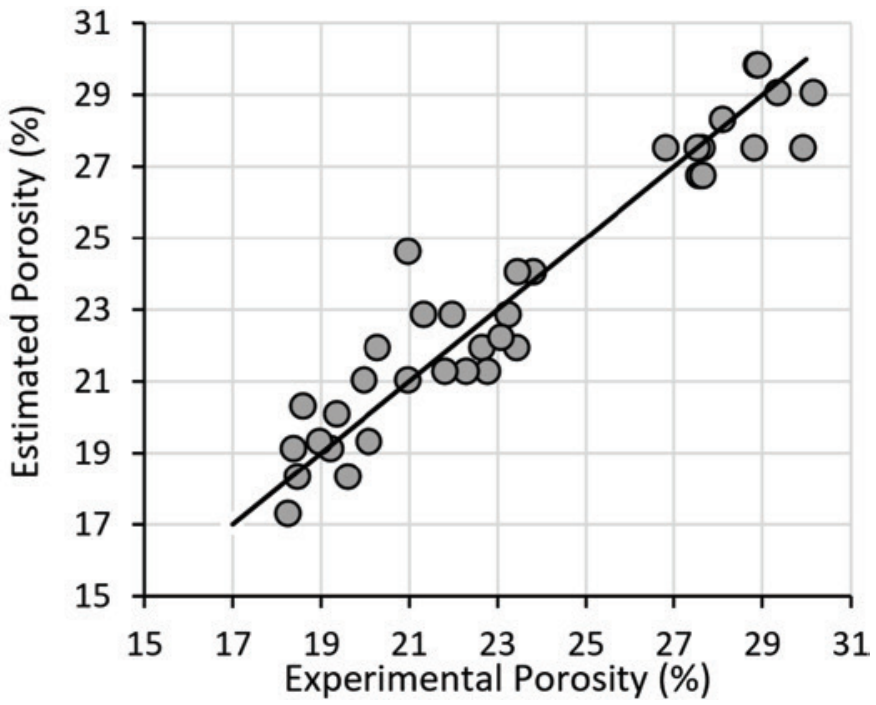

(b)

\section{Figure 4}

Relation between total porosity and ultrasonic pulse velocity (a) and validation of experimental and estimated data (b) 


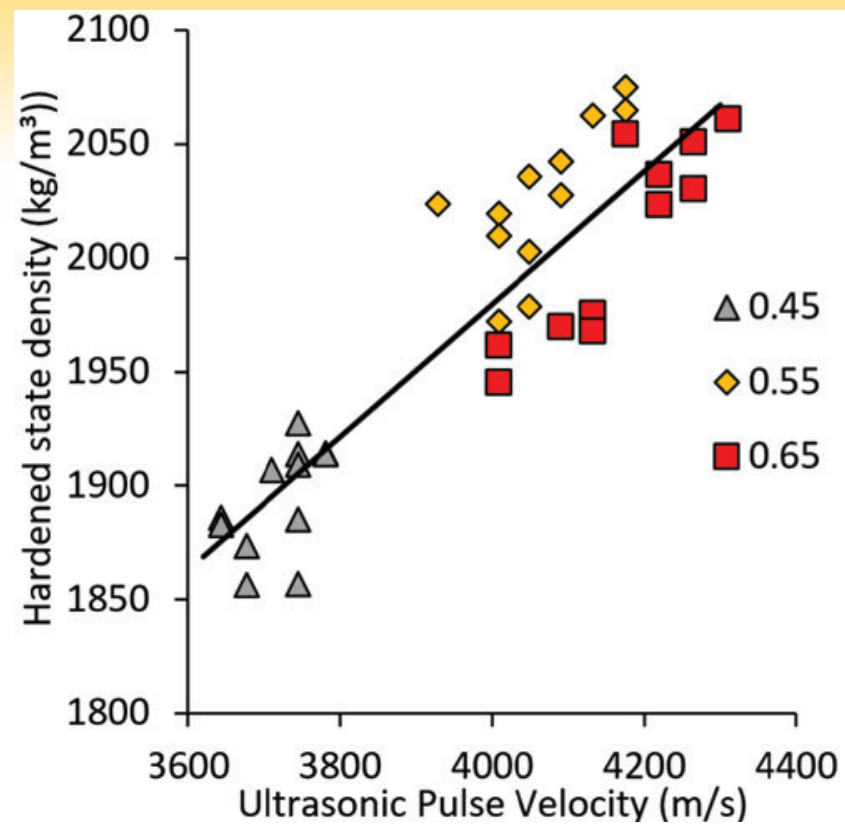

(a)

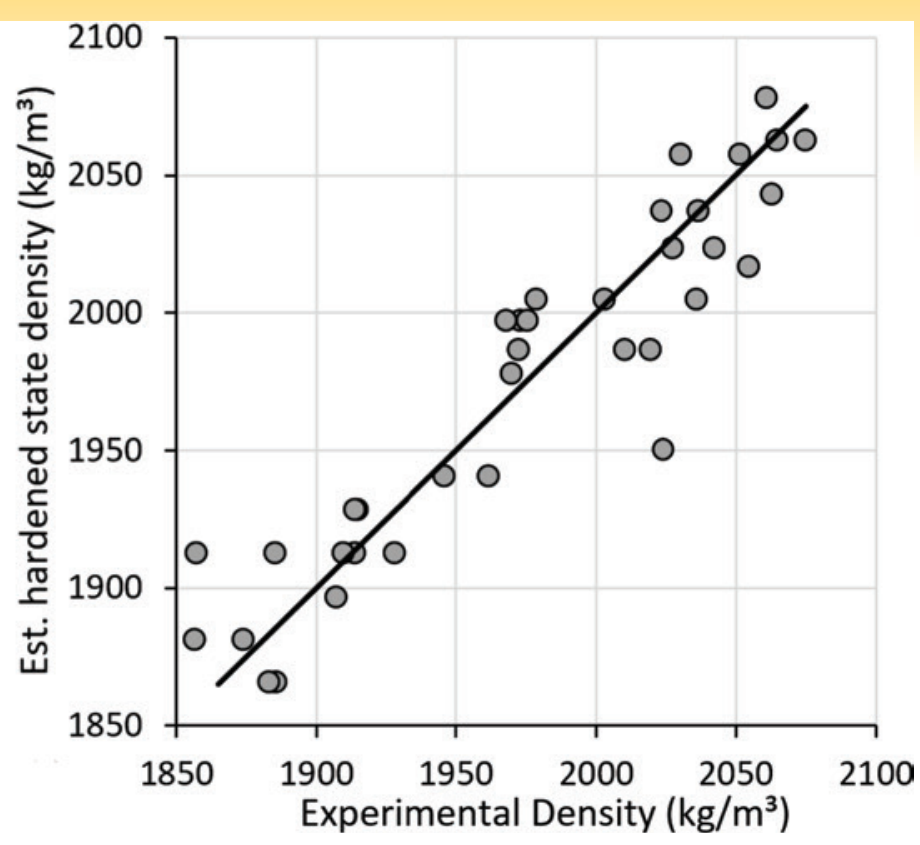

(b)

\section{Figure 5}

Hardened state density and ultrasonic pulse velocity (a) and validation of experimental and estimated data (b)

permeability lead to a lower value of UPV, which is related to higher porosities. This sheds light on the possibility of estimate the permeability of the pervious concrete with nondestructive tests. It is possible to estimate permeability $(k)$ through the independent variables UPV and P/Ag ratio by Equation 4.

$k=65.842+10.089 \cdot P / A g-0.01677 \cdot U P V$
Figure $6 \mathrm{~b}$ presents a comparison between the average experimental and estimated permeability for all specimens, including an equivalence line. Results reveal a relative prediction error of the estimation is $5,06 \%$, and a coefficient of correlation (R2) of 0.91 . Figure 7 shows the comparison between compressive and tensile strengths depending on the UPV. This correlation provides an estimation of these properties without the need for destructive tests.



(a)

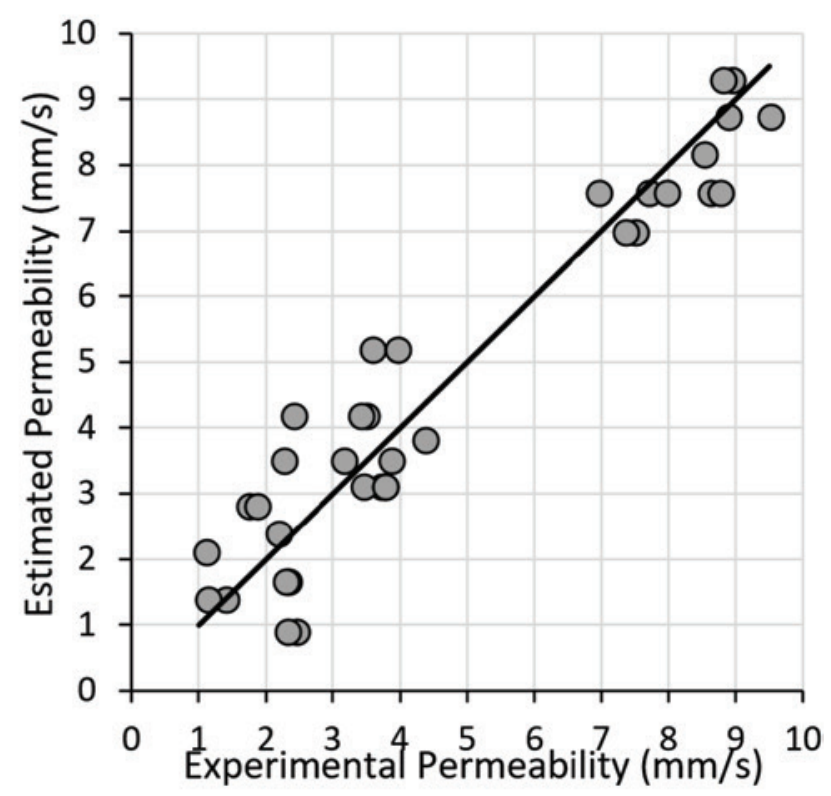

(b)

\section{Figure 6}

Relation between permeability and ultrasonic pulse velocity (a) and validation of experimental and estimated data (b) 


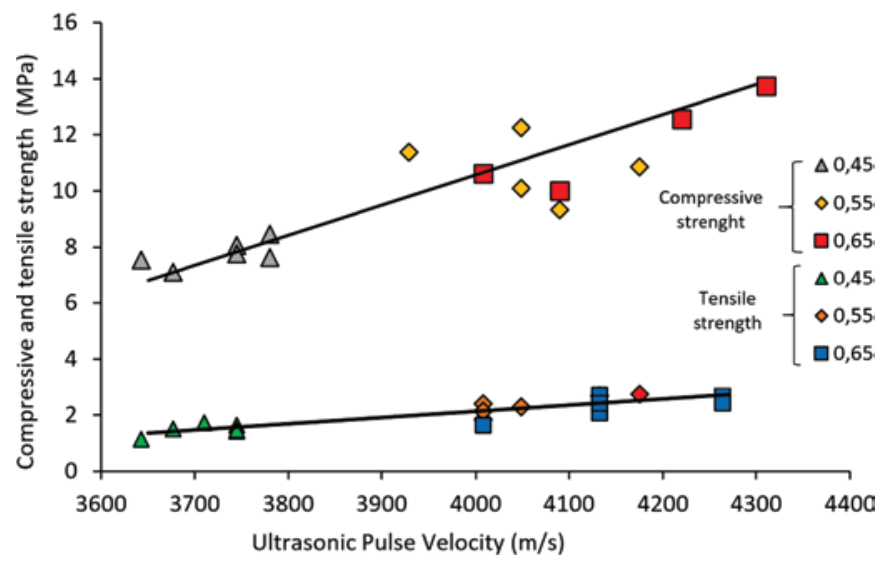

\section{Figure 7}

Relation between compressive strength and tensile strength with ultrasonic pulse velocity for three volumes P/Ag

Equations 5 and 6 present the relations to obtain the compressive and tensile strength, respectively, through the independent variables UPV and P/Ag ratio.

Figure 8 presents a comparison between the average experimental and estimated compressive and tensile strength for all specimens, including an equivalence line. Results reveal relative prediction errors of the estimations are $0,63 \%$ and $0,81 \%$, and coefficients of correlations $\left(\mathrm{R}^{2}\right)$ of 0.79 and 0.84 for compressive and tensile strength, respectively.

$\sigma_{C}=-18.56+6.418 \cdot P / A g+0.006297 \cdot U P V$

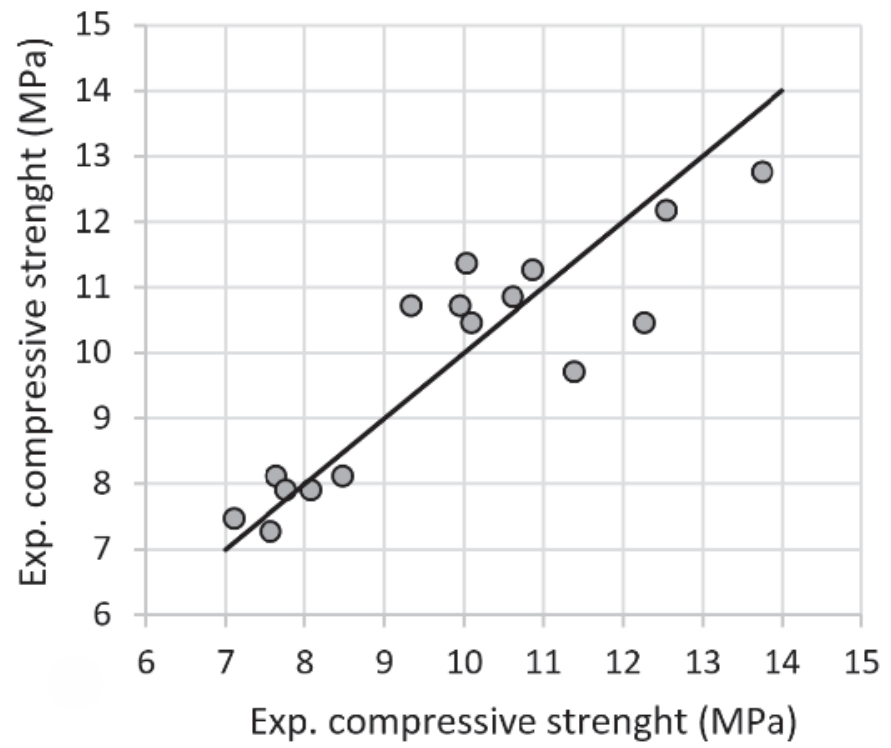

(a)
$\sigma_{T}=-9.4996-3.237 \cdot P / A g+0.003354 \cdot U P V$

It is worth highlighting a particular characteristic of pervious concrete concerning its rupture, in which predominantly it was the coarse aggregates that failed and not the P/Ag bonding layer, a behavior also observed by other authors [21].

The correlations presented suggest the potential that the application of nondestructive tests has to characterize pervious concrete, avoiding the need for core extraction and allowing to establish correlations with its properties. Thus, deeper studies are required to verify the influence of the pervious concrete constituent materials on the UPV. It is emphasized that all presented equations are only compatible with the materials used in this research. So, concretes produced with materials of different physical and chemical characteristics need to be tested and validated for the presented equations.

\section{Conclusions}

The application of the ultrasound method deserves special attention for the characterization of pervious concrete, due to the potential to develop analytical models for predicting properties from UPV. Ultrasonic pulse velocity results were between 3642 and $4262 \mathrm{~m} / \mathrm{s}$ for a variation of approximately $12 \%$ in porosity. Specimens with higher permeability presented higher porosity which leads to a higher value of UPV because the voids cause attenuation of the ultrasonic wave velocity. Moreover, the mechanical properties (compressive and tensile strengths) are inversely proportional to the UPV. With the UPV values of all mixtures, multivariable linear regressions were performed to estimate the properties of the pervious concrete, obtaining a high correlation coefficient, as follows: 0.91 (Porosity); 0.87 (Density); 0.91 (permeability); 0.79 and 0.84 (Compressive and tensile strength, respectively).

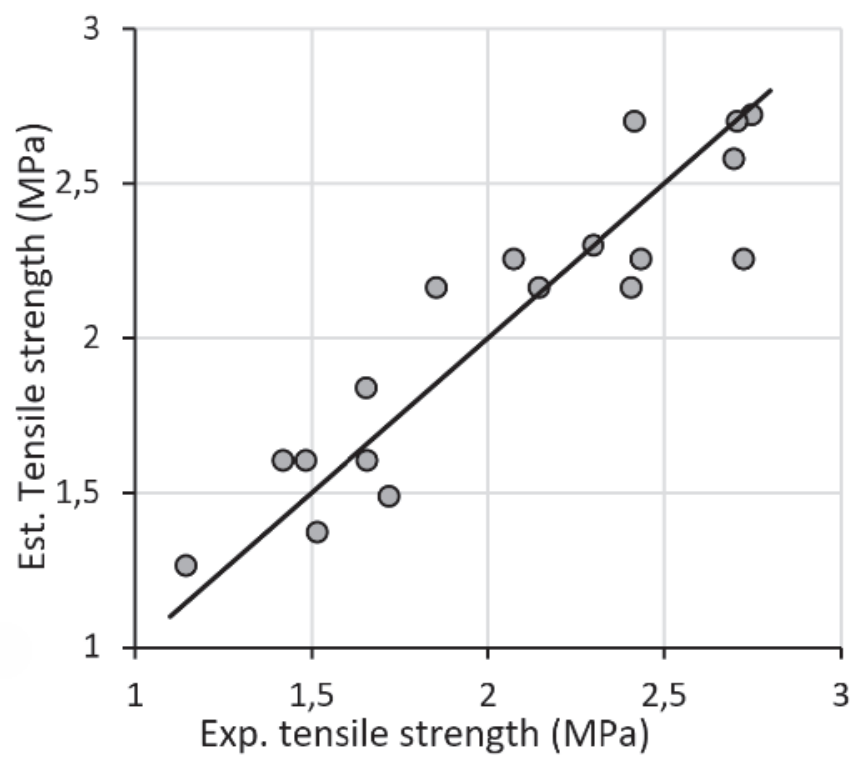

(b)

\section{Figure 8}

Validation of compressive (a) and tensile (b) strength, estimated and experimental 


\section{Acknowledgment}

The authors thank the Postgraduate Program in Civil Construction Engineering (PPGECC) at the Federal University of Paraná (UFPR) and the Department of Civil Engineering of UTFPR / Apucarana.

\section{Bibliographic references}

[1] TENNIS, P. D.; LEMING, M. L.; AKERS, D. J. Pervious concrete pavements. Technical report, EB302.02. Portland Cement Association, Skokie, Illinois, and National Ready Mixed Concrete Association, Silver Spring, Maryland, 32p, 2004.

[2] KIA, A.; WONG, H. S.; CHEESEMAN, C.R. Clogging in permeable concrete: A review. Journal of Environmental Management, v.193, p. 221-233, 2017.

[3] CAPUTO, H.P. Mecânica dos Solos e suas AplicaçõesFundamentos, v. 1, 234p, Rio de Janeiro, 1988.

[4] OSPINA, C. M. M.; ERAZO, C. H. B. Resistencia mecánica y condiciones de obra del concreto poroso en los pavimentos según el tipo de granulometría. Medellín, 2007.

[5] FERGUSON, B. K. Porous pavements, Boca Raton: CRC Press, London, 577p, 2005.

[6] KIM, H. K.; LEE, H. K. Influence of cement flow and aggregate type on the mechanical and acoustic characteristics of porous concrete. Applied Acoustics, v. 71, p. 607-615, 2010.

[7] HAGER, A. S. Sustainable Design of Pervious Concrete Pavements. PhD Dissertation, University of Colorado Denver, Department of Civil Engineering, Denver, CO, 2009.

[8] SABNIS G.M. Green building with concrete. Sustainable design and construction, 1nEd. Boca Raton, 320p, 2012.

[9] ASHLEY, E. Using Pervious Concrete to Achieve LEED Points. Concrete Infocus. National Ready Mixed Concrete Association, Silver Spring, MD, p. 1-6, 2008.

[10] AMERICAN CONCRETE INSTITUTE (ACI), 2010. Report on Pervious Concrete. ACl Committee 522. Report number: ACI 522R-10.

[11] NEITHALATH N.; DEO, O. Compressive response of pervious concretes proportioned for desired porosities. Construction and Building Materials, v. 25, p. 4181-4189, 2011.

[12] PIERALISI, R.; CAVALARO, S.H.P.; AGUADO. A Advanced numerical assessment of the permeability of pervious concrete. Cement and Concrete Research, v. 102, p. 149-160, 2017.

[13] MEININGER, R. C. No-Fines Pervious Concrete for Paving. Concrete International, v.10, p. 20-27, 1988.

[14] GHAFOORI, N.; DUTTA, S. Laboratory Investigation of Compacted No-Fines Concrete for Paving Materials. Journal of Materials in Civil Engineering, v. 7, n. 3, p. 183-191, 1995a.

[15] THO-IN, T.; SATA, V.; CHINDAPRASIRT, P.; JATURAPITAKKUL, C. Pervious highcalcium fly ash geopolymer concrete. Construction and Building Materials, v. 30, p. 366-371, 2012.

[16] SATA, V.; WONGSA, A.; CHINDAPRASIRT, P. Properties of pervious geopolymer concrete using recycled aggregates. Construction and Building Materials, v. 42, p. 33-39, 2013.
ZAETANG, Y.; WONGSA, A.; SATA, V.; CHINDAPRASIRT, $P$. Use of lightweight aggregates in pervious concrete. Construction and Building Materials, v. 48, p. 585-591, 2013.

BHUTTA, M. A. R.; HASANAH, N.; FARHAYU, N.; HUSSIN, M. W.; TAHIR, M. B. M.; MIRZA, J. Properties of porous concrete from waste crushed concrete (recycled aggregate). Construction and Building Materials, v. 47, p. 1243-1248, 2013.

[19] KUO, W. T.; LIU, C. C.; SU, D. S. Use of washed municipal solid waste incinerator bottom ash in pervious concrete. Cement and Concrete Composites, v.37, p. 328-335, 2013.

[20] NEITHALATH, N.; SUMANASOORIYA, M. S.; DEO, O. Characterizing pore volume, sizes, and connectivity in pervious concretes for permeability prediction. Materials Characterization, v. 61, p. 802-813, 2010.

[21] YAHIA, A.; KABAGIRE, D. New approach to proportion pervious concrete. Construction and Building Materials, v. 62, p. 38-46, 2014.

[22] NGUYEN, D. H.; SEBAIBI, N.; BOUTOUIL. M.; LELEYTER, L.; BARAUD, F. A modified method for the design of pervious concrete mix. Construction and Building Materials, v. 73, p. 271-282, 2014.

[23] COSTA, F. B. P.; LORENZI, A.; HASELBACH, L.; SILVA FILHO, L. C. P. Best practices for pervious concrete mix design and laboratory tests. REVISTA IBRACON DE ESTRUTURAS E MATERIAIS, v. 11, n. 5, p. 1151-1159, 2018. [24] CAVALARO, S. H. P.; BLANCO, A.; PIERALISI, R. Holistic modelling approach for special concrete: from fresh-to hardened-state. RILEM Technical Letters, v. 3. p. 84-90, 2018.

[25] AMERICAN SOCIETY FOR TESTING AND MATERIALS.. ASTM C1754 / C1754M, Standard Test Method for Density and Void Content of Hardened Pervious Concrete, ASTM International, West Conshohocken, PA, 2012.

[26] AMERICAN SOCIETY FOR TESTING AND MATERIALS. ASTM C1747 / C1747M, Standard Test Method for Determining Potential Resistance to Degradation of Pervious Concrete by Impact and Abrasion, ASTM International, West Conshohocken, PA, 2013.

[27] AMERICAN SOCIETY FOR TESTING AND MATERIALS. ASTM C1688 / C1688M, Standard Test Method for Density and Void Content of Freshly Mixed Pervious Concrete, ASTM International, West Conshohocken, PA, 2014.

[28] AMERICAN SOCIETY FOR TESTING AND MATERIALS...ASTM C1701 / C1701M, Standard Test Method for Infiltration Rate of In Place Pervious Concrete, ASTM International, West Conshohocken, PA, 2017.

[29] ASSOCIAÇÃO BRASILEIRA DE NORMAS TÉCNICAS. NBR 16416: Pavimentos permeáveis de concreto - Requisitos e procedimentos, Rio de Janeiro, 2015.

[30] OHDAIRA, E.; MASUZAWA, N. Water content and its effect on ultrasound propagation in concrete - the possibility of NDE. Ultrasonics, v. 38, p. 546-552, 2000.

[31] MALHOTRA, V.M., N. J. E. CARINO, N. J. E. Handbook of Nondestructive Testing of Concrete, CRC Press, Boca Raton, FL, USA, 2nd edition, 2004.

[32] AMERICAN SOCIETY FOR TESTING AND MATERIALS. 
ASTM C597, Pulse velocity through concrete, ASTM International, West Conshohocken, PA, 1989.

[33] CHANDRAPPA, A. K.; BILIGIRI, K. P. Investigations on Pervious Concrete Properties Using Ultrasonic Wave Applications. Journal of Testing and Evaluation, v. 45, n.5, p.1736-1749, 2017.

[34] CHANDRAPPA, A. K.; BILIGIRI, K. P. Influence of mix parameters on pore properties and modulus of pervious concrete: an application of ultrasonic pulse velocity. Materials and Structures, v. 49, p. 5255-5271, 2016c.

[35] AMINI, K.; WANG, X.; DELATTE, N. Statistical Modeling of Hydraulic and Mechanical Properties of Pervious Concrete Using Nondestructive Tests. Journal of Materials in Civil Engineering, v. 30, n. 6, p. 1-8, 2018.

[36] ASSOCIAÇÃO BRASILEIRA DE NORMAS TÉCNICAS. NBR NM 248: Agregados -Determinação da composição granulométrica, Rio de Janeiro, 2003.

[37] ASSOCIAÇÃO BRASILEIRA DE NORMAS TÉCNICAS. NBR NM 45: Agregados - Determinação da massa unitária e do volume de vazios. Rio de Janeiro, 2006.

[38] ASSOCIAÇÃO BRASILEIRA DE NORMAS TÉCNICAS.. NBR 7809: Agregado graúdo - Determinação do índice de forma pelo método do paquímetro - Método de ensaio, Rio de Janeiro, 2006.

[39] ZINGG, T. Beiträg zur schotteanalysis. Diss.-Druckerei A.-O. Gebr. Leemann \& Co., 107p., 1935.

[40] LIAN, C.; ZHUGE, Y. Optimum mix design of enhanced permeable concrete - An experimental investigation. Journal of Environmental Management, v.193, p. 221-233, 2017.

[41] LIM, E.; TWAN, K. H.; FWA, T. F. Effect of mix proportion on strength and permeability of pervious concrete for use in pavement. Journal of the Eastern Asia Society for Transportation Studies, v. 9, p. 1565-1575, 2013.

[42] IBRAHIM, A.; MAHMOUD, E.; YAMIN, M.; PATIBANDLA, V. C. Experimental study on Portland cement pervious concrete mechanical and hydrological properties, Construction and Building Materials, v. 50, p. 524-529, 2014.

[43] ASSOCIAÇÃO BRASILEIRA DE NORMAS TÉCNICAS. NBR 16697: Cimento Portland- Requisitos, Rio de Janeiro, 2018.

[44] SCHAEFER, V.; WANG, K.; SULEIMAN, M.; KEVERN, J. Mix design development for pervious concrete in cold weather climates. National Concrete Pavement Technology Center, 83p, 2006.

[45] ASSOCIAÇÃO BRASILEIRA DE NORMAS TÉCNICAS. NBR 5739: Concreto - Ensaio de compressão de corpos de prova cilíndricos, Rio de Janeiro, 1994.

[46] ASSOCIAÇÃO BRASILEIRA DE NORMAS TÉCNICAS. NBR 7222: Concreto e argamassa - Determinação da resistência à tração por compressão diametral de corpos de prova cilíndricos, Rio de Janeiro, 2011.

[47] CARRIÓN, A.; GENOVÉS, V.; GOSÁLBEZ, J.; MIRALLES, R.; PAYÁ, J. Ultrasonic signal modality: A novel approach for concrete damage evaluation. Cement and Concrete Research, v. 101, p. 25-32, 2017. 